\title{
RESEARCH PAPER \\ POTENTIAL GROUNDWATER POLLUTION FROM IMPROPER OIL AND METAL WASTE DISPOSAL IN SUAME, GHANA
}

\author{
*E. K. Appiah-Adjei ${ }^{1}$, N. F. Appiah ${ }^{1}$ and K. A. Adjei ${ }^{2}$ \\ ${ }^{1}$ Department of Geological Engineering, KNUST, Kumasi \\ ${ }^{2}$ Department of Civil Engineering, KNUST, Kumasi \\ *Corresponding author: ekappiah-adjei.soe@knust.edu.gh
}

\begin{abstract}
Suame is an industrialized hub in Kumasi, Ghana, that is noted for vehicle repairs and servicing, sale of automobile spare parts, and metal fabrication. Some of these activities generate huge volumes of waste oil and metals that are often disposed off indiscriminately into the environment. These could pose a threat to the quality of groundwater in the area, especially if they continuously accumulate in the environment. This study, therefore, investigated the potential impact of the waste disposal on groundwater quality in the area. The methods employed involved mapping all the potential waste oil spillage sources and sampling the soils in such areas (at 0 - 30 and $30-60 \mathrm{~cm}$ depths) and groundwater supply points for laboratory analyses to determine the presence of the waste. In all, 36 samples (comprising 12 soil and 24 groundwater) were analysed for the presence of heavy metals including $\mathrm{Cd}, \mathrm{Ni}, \mathrm{Cu}, \mathrm{Pb}, \mathrm{Zn}$ and $\mathrm{Cr}$, which were used as trace elements for the presence of the waste in the samples. Computed geo-accumulation indices from the results show the soils are moderately to heavily polluted with $\mathrm{Cd}$ and $\mathrm{Pb}$ whilst the groundwater, when compared to the WHO drinking water guidelines, is polluted with $\mathrm{Pb}$ and Ni. Although the source of the high Pb content observed could be attributed to its transport directly from the activities in the area, the presence of high Ni makes it inconclusive since the Ni in the soil was within the concentration expected of the parent rock geochemistry. This notwithstanding, the study has indicated that groundwater in the area is not safe for human consumption unless the lead and nickel concentrations are reduced to acceptable standard for drinking.
\end{abstract}

Keywords: Groundwater quality, pollution, waste disposal, Suame, Ghana

\section{INTRODUCTION}

Groundwater plays a very important role in meeting the water needs of many communities in the world. In Ghana, it serves as the main source of water supply for inhabitants in rural areas and as a supplementary source of meeting the increasing water demands in urban areas. Mostly, the resource is considered 'pure' and, 


\section{Appiah-Adjei et al.}

generally, assumed to be of very good quality due to the 'filtering' action that takes place in its transport through geologic media (Lewis et al., 1982). However, this view may no longer be valid in many instances since increasing industrialization and agriculture activities due to population growth continue to generate tonnes of domestic, industrial and agricultural wastes, which are sometimes disposed off into the environment improperly and transported to the underlying aquifers to pollute them. Besides, groundwater may, naturally, be contaminated through its interactions with geologic media when it dissolves undesirable concentrations of inorganic chemicals from the geologic media (Fawell and Nieuwenhuijsen, 2003; Todd and Mays, 2005).

Groundwater pollution from anthropogenic activities such as mining (Xu and Usher, 2006; Lusilao-Makiese et al., 2013), smelting and metal fabrications (Garg and Totawat, 2004; Hu et al., 2014; Ettler, 2016), sewage and waste disposal (Chettri and Smith, 1995; Kacaroglu and Gunay, 1997; Adepelumi et al., 2001), use of fertilizers (Chen et al., 2007; Parris, 2011; Shen et al., 2011), and leakage/spillage of stored oil and gas (Ojiegbe, 2006; Haest et al., 2010) have been reported in several areas. These activities often release harmful chemicals into the environment, which are then transported to the aquifers through recharge waters or interactions with surface water when deposited in them. The common potentially toxic contents of the effluents from these activities are heavy metals such as Chromium (Cr), Cadmium $(\mathrm{Cd})$, Lead $(\mathrm{Pb})$, Zinc $(\mathrm{Zn})$, Copper $(\mathrm{Cu})$, Nickel (Ni), and Mercury $(\mathrm{Hg})$, which when dissolved in water at even lower concentrations render it unsafe for drinking. These metals are responsible for deaths caused by kidney and liver diseases (Friberg et al., 1986) and can, significantly, inhibit the growth of plants and reduce their yields (Chibuike and Obiora, 2014).

Research has shown that there is always a connection between the crude oil contamination and increase in heavy metal concentration in soils around oil production facilities (Newbury, 1997). Unlike many organic pollutants, which eventually degrade to carbon dioxide and water, heavy metals tend to accumulate in the environment and can be transported from one environment to the other depending on their chemical mobility (Duffus, 2002; Ahmadipour et al., 2014). Thus they could be used to trace the source of pollution in an environment and evaluate its toxicity (Richard and Richard, 1977).

The operational activities in Suame, an industrialized area in Kumasi, Ghana, generate lots of metal and oil wastes, which are disposed off indiscriminately into the environment and could pollute the groundwater that the inhabitants rely on to meet their daily water needs. Unfortunately, the groundwater is deemed 'pure' and not treated before consumption like the surface water; hence its pollution could have very serious health implications on the populace. This study, therefore, evaluates the potential impact of waste oil and metal disposal on groundwater quality in the area. The methods employed involved mapping all the potential groundwater supply points and pollution sites in the area and tracing the presence of heavy metals in the groundwater and soils (at different depths) to evaluate their possible pollution from activities in the area.

\section{MATERIALS AND METHODS \\ Description of study area}

The study area, Suame, is located in the $\mathrm{Ku}$ masi Metropolis of Ghana within latitudes $6^{\circ} 35^{\prime}$ to $6^{\circ} 40^{\prime} \mathrm{N}$ and longitudes $1^{\circ} 30^{\prime}$ to $1^{\circ} 35^{\prime} \mathrm{W}$. The area, known to have been established in the 1960 s, is highly industrialized with over 12,000 workshops involved in vehicle repair and servicing, metal fabrication, automobile spare parts sales, and micro to medium sized enterprises employing over 200,000 workers (Obeng, 2002; Azongo, 2007; Adeya, 2008). These workshops are mainly concentrated in a community of about $0.5 \mathrm{~km}^{2}$ within the study area called "Magazine" (shown in Fig. 1). 
Available estimates indicate that activities in the area comprise $60 \%$ vehicle repair, maintenance and servicing, 20\% manufacturing, fabrication and machining, and $20 \%$ sales and services (Obeng, 2002; SMIDO, 2012).

The topography of the area is generally undulating with elevations ranging from 250 to 350 $\mathrm{m}$ above sea level. The area falls within the moist semi-deciduous forest zone of Ghana and experiences a double maxima rainfall regime that spans from March to November with a relatively dry period in August. The mean annual rainfall and temperature of the area computed from daily data spanning from 1951 to 2011 are $1410 \mathrm{~mm}$ and $26^{\circ} \mathrm{C}$ respectively. The geology of the area is mainly made up of metasediments intruded by basin type granitoids (Kesse, 1985). The rocks are highly fractured and deeply weathered; thus making borehole prospects in the area fair to good, especially in the areas where quartz veins dominate.

In the past, water supply to the populace in the area was mainly from two surface water treatment plants within the Kumasi Metropolis. However, population growth and unreliable supply from the treatment plants, sometimes, have led to many homes and communities in the area switching to hand-dug wells and boreholes to meet their daily water needs. Due to the industrialization of the study area, a lot of liquid and solid wastes comprising metals, oil and biodegradable materials are generated. Large quantities of these wastes are often improperly disposed off in open spaces and drains in the area (JICA, 2013; Acheampong et al., 2016) and these sometimes end up in both the surface water and groundwater sources, which the inhabitants depend on for their daily water supply needs.

\section{Sampling and laboratory analyses}

As part of the study, all the groundwater supply points (i.e. boreholes, hand-dug wells and springs) and potential oil spillage sites (i.e. garages, filling stations and lube bays for oil change) in the area were mapped to know their distribution. Alongside the mapping, questionnaires were administered to the inhabitants and artisans to seek information on historical groundwater quality in the area and the quantity of spillages from the potential pollution sites. The information gathered through these processes contributed significantly to the planning and selection of sampling points.

Thirty-six (36) samples, comprising 24 groundwater and 12 soil samples were collected from the study area for laboratory analyses to evaluate the potential groundwater pollution from the improper oil and metal disposal in the area. Fig. 1 shows the distribution of the sampling locations in the study area. The 24 groundwater samples, evenly distributed across the study area, were collected from 19 hand-dug wells, four boreholes and one spring just after the rainy season. Nine of these water samples were taken within Magazine, where the industrial activity is very intense, whilst the remaining samples were taken at the other areas within Suame. The groundwater was sampled into 500 $\mathrm{ml}$ volume plastic bottles following standard sampling protocols (APHA, 1989), kept at $4^{\circ} \mathrm{C}$ in an ice chest containing ice cubes, and transported to the laboratory within the same day for analyses. The twelve soil samples were taken at six different locations within the Magazine area (Fig. 1), which were close to waste disposal sites. The samples were obtained by hand digging, collected with a stainless steel spatula and kept in labelled plastic bags. At each location, two samples were taken at depths of $0-30 \mathrm{~cm}$ and $30-60 \mathrm{~cm}$ for the laboratory analyses.

At the laboratory, all the samples were analysed for the presence of the heavy metals $\mathrm{Cd}, \mathrm{Ni}$, $\mathrm{Cu}, \mathrm{Pb}, \mathrm{Zn}$ and $\mathrm{Cr}$. Commonly, these metals are found in areas with activities similar to the study area; hence they could be used as good indictors to trace transport of the waste oil and metal disposed in the area into the aquifers. The concentration of heavy metals in the groundwater samples were measured using the Atomic Absorption Spectrophotometer (AAS) whilst its contents in the soil samples were measured 


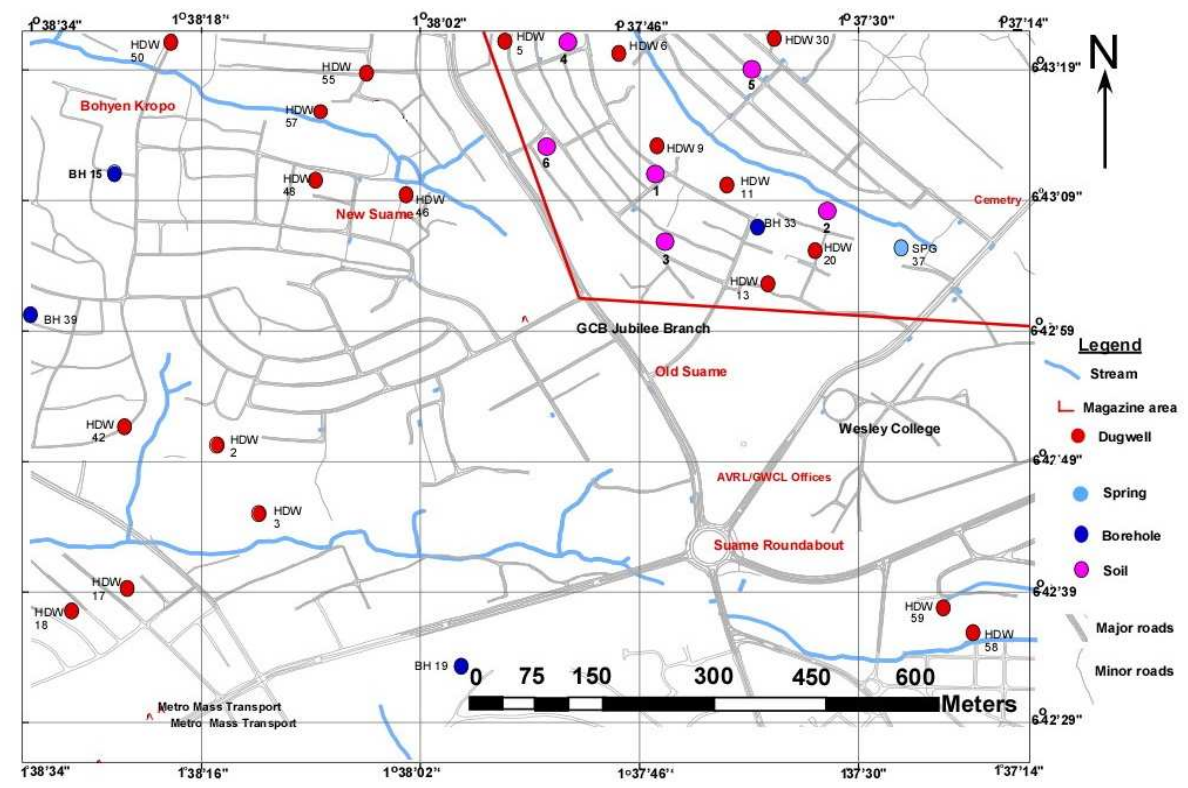

Fig. 1: Distribution of sampling locations in the study area (Magazine is the area bounded red on the map)

with the X-Ray Fluorescence spectrometer (XRF).

\section{Data analyses}

Generally, the suitability of water for any particular use is assessed by comparing it to an acceptable quality standard or guideline developed to ensure its safe use. Over the years, the World Health Organization (WHO) has developed a series of water quality guidelines that indicate the various health risks associated with exposure to unwholesome water (WHO, 2011), which have been adopted or modified for local use by most countries. These guidelines represent the concentration of a constituent in water that would not result in any significant health risk over a lifetime of consumption and have been applied in several studies worldwide including Ghana (Apambire et al., 1997; AbdulRazak et al., 2009; Ansa-Asare et al., 2009; Nkansah et al., 2010; Annapoorna and Janardhana, 2015; Krishna kumar et al., 2015). Thus the measured heavy metal concentrations in the groundwater samples from the laboratory were analysed spatially and in comparison with the acceptable WHO (2011) guideline values for drinking water. The spatial analyses involved combining the field data, especially location coordinates of the sampling points, with the quality parameters to create maps for graphical evaluation of the variation and distribution of groundwater quality in the study area.

Also, the index of geoaccumulation $\left(I_{\text {geo }}\right)$, used in determining the enrichment of metals in soils relative to their background values, was calculated to aid in assessing the extent of heavy metal pollution in the soils. This index is fully explained in Müller (1969) and was computed using Eqn. (1):

$$
I_{g e}-\log _{2} \frac{c_{\mathrm{n}}}{1.5 R_{\mathrm{n}}}
$$


where $\mathrm{Cn}$ is the measured concentration of metal in the soil and $B n$ is the geochemical background value in the earth crust (i.e. crustal value). The crustal values used in the computations were obtained from Taylor (1964). The geochemical indices obtained from the computations were used to determine the heavy metal pollution of the soils based on the categorization in Table 1. for drinking and no case of water related disease has been reported in the area. Surprisingly, some affirmed that the groundwater was better in taste and, some even, preferred using it to the treated pipe-borne water. However, $25 \%$ of both the hand-dug wells and boreholes directed their water to reservoirs for filtering before supplying them for use whereas about $10 \%$ of the HDWs were also purged at regular periods

Table 1: Classes of pollution based on index of geoaccumulation (Müller, 1969)

\begin{tabular}{lll}
\hline Class & $\mathbf{I}_{\text {geo }}$ Value & Soil quality \\
\hline 0 & $<0$ & Unpolluted \\
1 & $0-1$ & Unpolluted to moderately polluted \\
2 & $1-2$ & Moderately polluted \\
3 & $2-3$ & Moderately to heavily polluted \\
4 & $3-4$ & Heavily polluted \\
5 & $4-5$ & Heavily to extremely polluted \\
6 & $>5$ & Extremely polluted \\
\hline
\end{tabular}

\section{RESULTS AND DISCUSSION}

Mapping and questionnaire administration

A total of 63 groundwater supply points comprising 46 hand-dug wells (HDW), nine boreholes (BH) and eight springs (SPG) were mapped in the study area. Out of these, 27 were located within the Magazine area where industrial activities are more intensive while the remaining ones were located in the nearby communities. The HDWs were enclosed with concrete cases above the ground and covered either with a metal or wooden slab with about $90 \%$ of them having interior concrete linings. Also, 62 $\%$ of the HDWs were bucket-drawn whilst the remaining $11 \%, 18 \%, 3 \%$ and $6 \%$ were fitted with hand pumps, mechanized, abandoned and uncompleted, respectively.

Generally, the questionnaire responses, based on the specific questions asked, indicate that the quality of groundwater in the area was good for purposes of cleaning the well and water. These practices were very typical in areas where the water is commercialized. The static water elevation in the area ranges from 186 $294 \mathrm{~m}$ with an average of $269 \mathrm{~m}$ above mean sea level.

Fig. 2 shows the distribution of the mapped potential oil waste pollution sites (i.e. garages and filling stations) and annual spillages of oil in the area. It is observed that most of the garages are clustered within the Magazine area. The questionnaire responses indicate that waste oil from the garages are usually collected by the operators and sold to sawmill operators who use it to preserve wood and lubricate their chainsaws. However, most of the garages do not have efficient means of collecting the waste oil; hence lots of them still spill into the environment and have even hardened portions of the soil in some areas. The estimated oil waste 


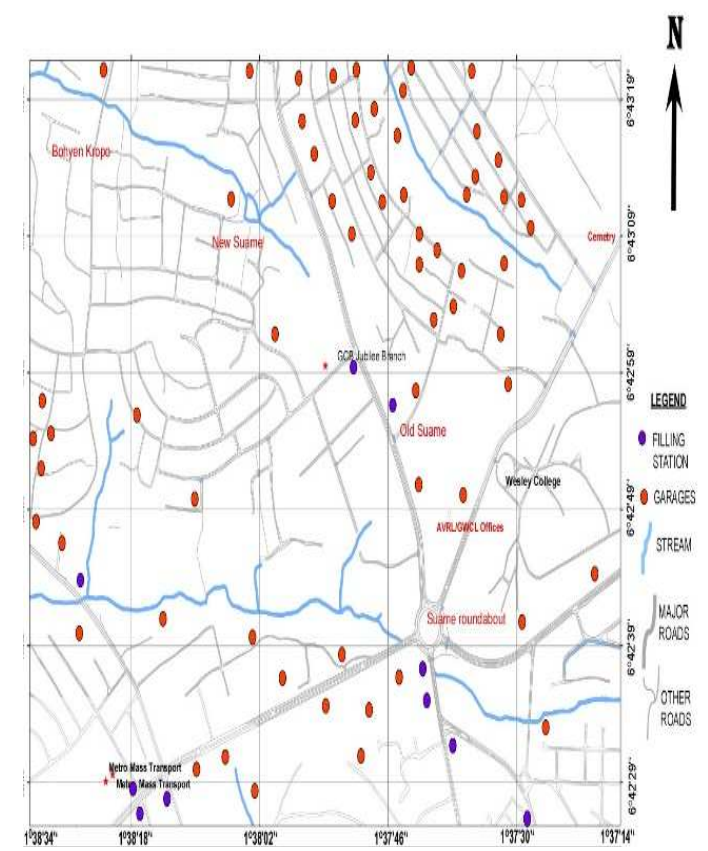

(a)

N

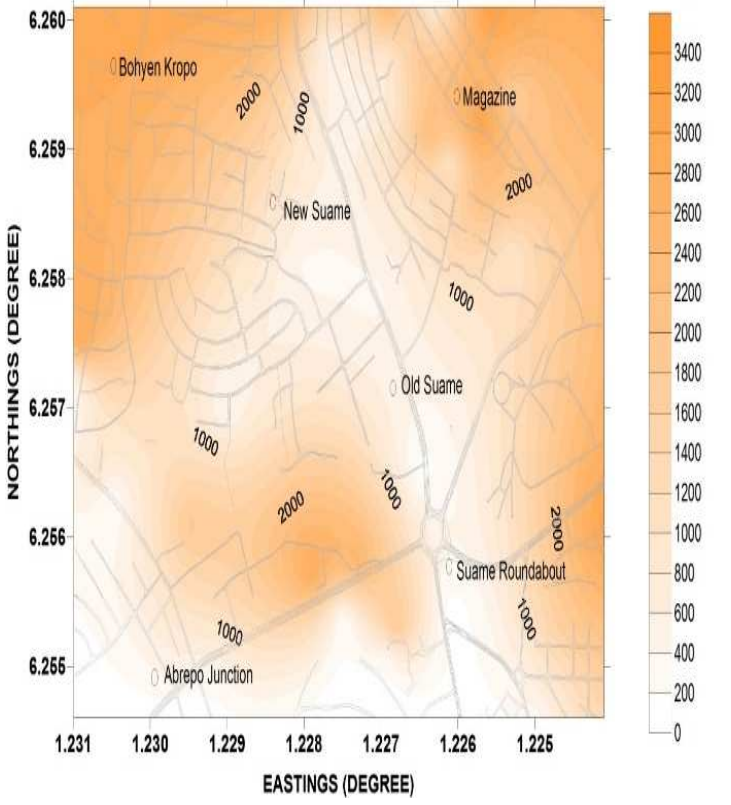

(b)

Fig. 2: Distribution of (a) potential oil waste pollution sites and (b) annual waste oil spillages from the garages in Suame area

spilled by the garages in the area ranges from 203 to 3,120 litres per year with a total of 58,032 litres of waste oil spilled to the environment annually and an average of 1,415 litres of waste oil per year per garage. These estimates were based on the questionnaire responses with respect to the number and types of vehicles serviced by the garages and the quantities of used oil spilled to the environment in the process. Comparatively, the filling stations spill very low amounts of oil, recording a total of 2,263 litres per year, because they have relatively efficient ways of managing their activities than the garages.

\section{Heavy metals in soils}

Table 2 presents the measured concentrations of heavy metals in the soils, which generally vary across the area and with depth. However, their mean concentrations were in the order $\mathrm{Cr}$ $>\mathrm{Zn}>\mathrm{Pb}>\mathrm{Cu}>\mathrm{Ni}>\mathrm{Cd}$ and each decreased with depth except for $\mathrm{Cr}$, which increased with depth. Similarly, the calculated geoaccumulation indices for the heavy metals in the soil samples at the $0-30 \mathrm{~cm}$ and $30-60 \mathrm{~cm}$ depths are presented in Table 3 and they each vary with depth.

The concentration of Cadmium in the soil at both depths exceed the crustal value (Taylor, 1964) and is very evident in the computed $I_{g e o}$, which indicates that the soil is moderately to extremely polluted with Cd (Müller, 1969). The pattern of its distribution within Magazine area, however, differs at both depths (Fig. 3). It increases in the north-eastern direction from the centre at the $0-30 \mathrm{~cm}$ depth, but decrease radially away from the centre at the $30-60 \mathrm{~cm}$ 
Impact of waste disposal on groundwater quality in Suame... 26

Table 2: Concentration (ppm) of heavy metals in the soils at $0-30 \mathrm{~cm}$ and $30-60 \mathrm{~cm}$ depths

\begin{tabular}{cccccccccccccc}
\hline \multicolumn{1}{c}{ 0-30 cm depth } & \multicolumn{1}{c}{ 30-60 cm depth } \\
\hline $\mathrm{SP}$ & $\mathrm{Cd}$ & $\mathrm{Ni}$ & $\mathrm{Cu}$ & $\mathrm{Pb}$ & $\mathrm{Zn}$ & $\mathrm{Cr}$ & $\mathrm{Cd}$ & $\mathrm{Ni}$ & $\mathrm{Cu}$ & $\mathrm{Pb}$ & $\mathrm{Zn}$ & $\mathrm{Cr}$ \\
1 & 1.6 & 19 & 45.7 & 65.6 & 213.9 & 526 & 7.6 & 34.7 & 173.4 & 592.9 & 745.7 & 134.0 \\
2 & 1.5 & 7.7 & 11.2 & 28.6 & 37.6 & 67 & 1.4 & 12.2 & 11.6 & 23.5 & 148.2 & 763.0 \\
3 & 1.7 & 18.4 & 60.1 & 83.5 & 161.1 & 141 & 1.8 & 21.7 & 16.3 & 1.6 & 21.5 & 378.0 \\
4 & 1.7 & 11.5 & 126.5 & 195.3 & 325.1 & 116 & 1.5 & 16.8 & 15.5 & 1.8 & 32.2 & 351.0 \\
5 & 11.9 & 27.7 & 151.6 & 521.8 & 819.7 & 116 & 1.5 & 19.3 & 19.5 & 1.0 & 18.7 & 574.0 \\
6 & 2.0 & 76.8 & 531.9 & 192.8 & 273.8 & 1077 & 2.1 & 30.9 & 100.2 & 38.7 & 67.5 & 698.0 \\
Mean & 3.4 & 26.9 & 154.5 & 181.3 & 305.2 & 340.5 & 2.7 & 22.6 & 56.1 & 109.9 & 172.3 & 483.0 \\
& & & & & & & & & & & & & \\
$\mathrm{C}_{\mathrm{v}}$ & 0.15 & 75.0 & 50.0 & 12.5 & 70.0 & 100.0 & 0.15 & 75.0 & 50.0 & 12.5 & 70.0 & 100.0 \\
\hline
\end{tabular}

$C_{v}$ is crustal value (Taylor, 1964); SP means sample

Table 3: Geoaccumulation indices for heavy metals at $0-30 \mathrm{~cm}$ and $30-60 \mathrm{~cm}$ depths

\begin{tabular}{cccccccccccccc}
\hline \multicolumn{10}{c}{ 0-30 cm depth } & \multicolumn{10}{c}{ 30-60 cm depth } \\
\hline $\mathrm{SP}$ & $\mathrm{Cd}$ & $\mathrm{Ni}$ & $\mathrm{Cu}$ & $\mathrm{Pb}$ & $\mathrm{Zn}$ & $\mathrm{Cr}$ & $\mathrm{Cd}$ & $\mathrm{Ni}$ & $\mathrm{Cu}$ & $\mathrm{Pb}$ & $\mathrm{Zn}$ & $\mathrm{Cr}$ \\
1 & 2.8 & -2.6 & -0.7 & 1.8 & 1.0 & 1.8 & 5.1 & -1.7 & 1.2 & 5.0 & 2.8 & -0.2 \\
2 & 2.7 & -3.9 & -2.7 & 0.6 & -1.5 & -1.2 & 2.6 & -3.2 & -2.7 & 0.3 & 0.5 & 2.3 \\
3 & 2.9 & -2.6 & -0.3 & 2.2 & 0.6 & -0.1 & 3.0 & -2.4 & -2.2 & -3.6 & -2.3 & 1.3 \\
4 & 2.9 & -3.3 & 0.8 & 3.4 & 1.6 & -0.4 & 2.7 & -2.7 & -2.3 & -3.4 & -1.7 & 1.2 \\
5 & 5.7 & -2.0 & 1.0 & 4.8 & 3.0 & -0.4 & 2.7 & -2.5 & -1.9 & -4.2 & -2.5 & 1.9 \\
6 & 3.2 & -0.6 & 2.8 & 3.4 & 1.4 & 2.8 & 3.2 & -1.9 & 0.4 & 1.0 & -0.6 & 2.2 \\
\hline
\end{tabular}

depth. The source of the high Cd content could be attributed to the improper disposal of wastes from vehicle servicing, metal plating and used batteries in the area.

Similar to the $\mathrm{Cd}$, the concentrations of both $\mathrm{Cu}$ and $\mathrm{Zn}$ in the topsoil were mostly above the crustal value, but decreased to below it at depth in all, but two of the sites. However, the soil is described as unpolluted to moderately polluted with both $\mathrm{Cu}$ and $\mathrm{Zn}$ based on their $I_{\text {geo }}$. The two sites with increased $\mathrm{Cu}$ and $\mathrm{Zn}$ at depth were located downslope and closer to the stream running through the area; hence, they may have received some depositions from the upslope areas. Commonly, wastes from welding and scrap metal fabrication of automobile body parts and wiring produced from copper could be the source of the high $\mathrm{Cu}$ in the soils. On the other hand, electroplating and galvanizing activities as well as the improper disposal of waste from zinc-carbon batteries in the area could be the anthropogenic source of the $\mathrm{Zn}$ metal.

Unlike the $\mathrm{Cd}$, the $\mathrm{Pb}$ concentrations exceeded the crustal values in the top soil $(0-30 \mathrm{~cm})$ and decreased sharply at the $30-60 \mathrm{~cm}$ depth, 

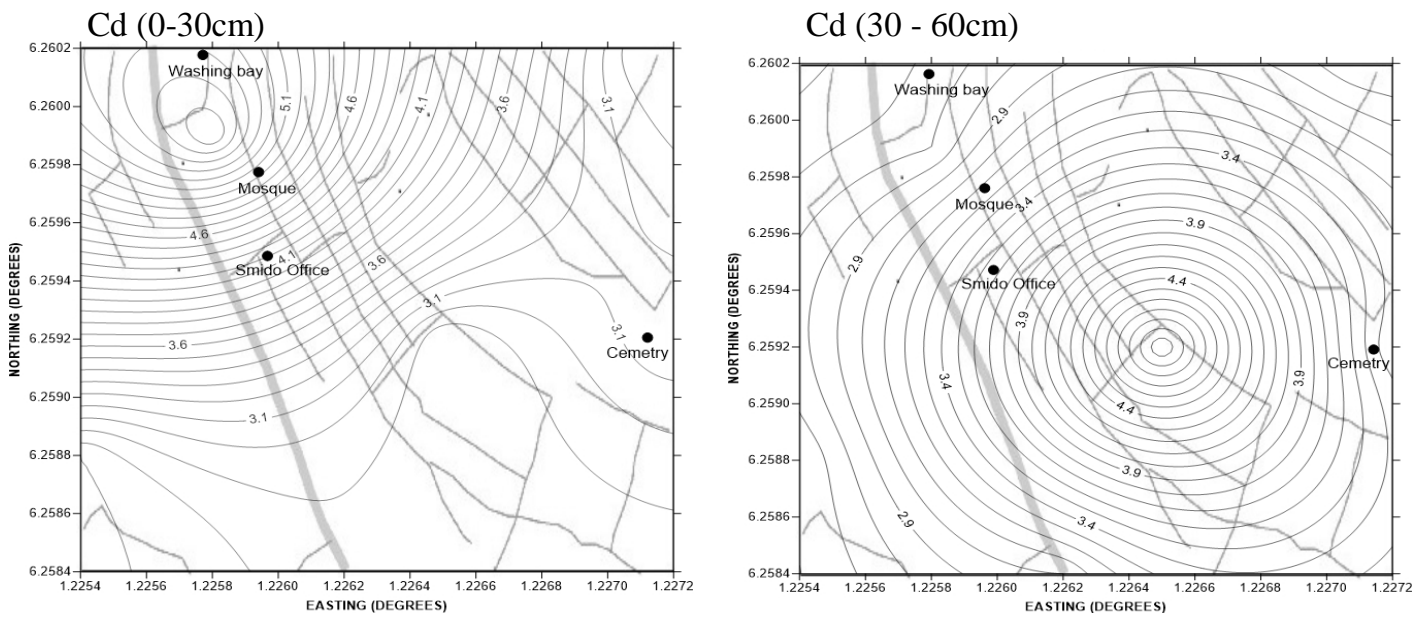

$\mathrm{Pb}(0-30 \mathrm{~cm})$

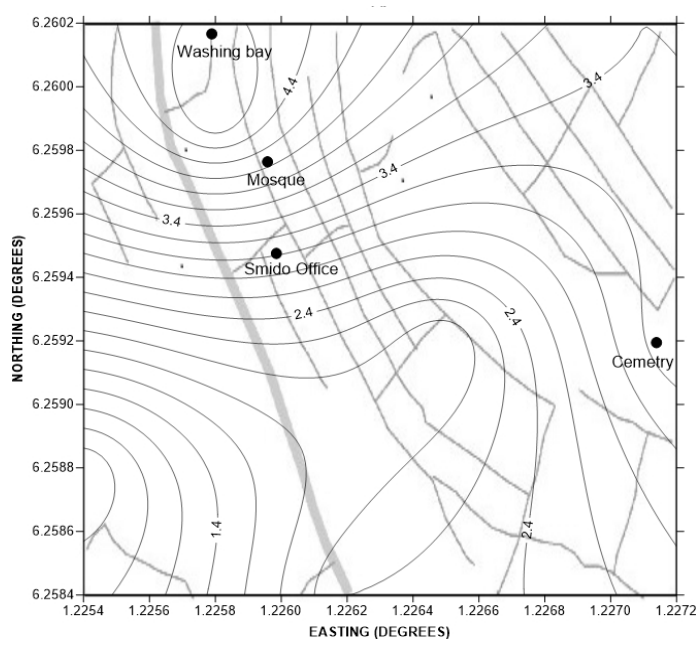

$\mathrm{Pb}(30-60 \mathrm{~cm})$

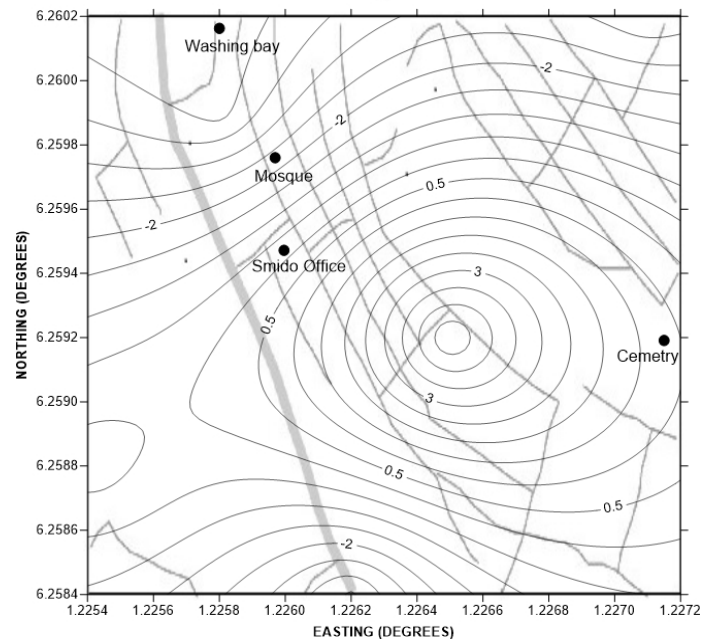

Fig. 3: Distribution of geoaccumulation indices of $\mathrm{Cd}$ and $\mathrm{Pb}$ in the soils of the Magazine area in Suame at $0-30 \mathrm{~cm}$ and $30-60 \mathrm{~cm}$ depths

except for site 1 , with half of them below the crustal value. This is reflected in the computed $\mathrm{I}_{\text {geo }}$, which indicates that the soil is moderately to heavily polluted with $\mathrm{Pb}$ in the top soil, but unpolluted to heavily polluted at bottom soil. The extent of its pollution in the area (Fig. 3) increases northwards, but is unpolluted in the same direction at the $30-60 \mathrm{~cm}$ depth. The cause of the high $\mathrm{Pb}$ accumulation within the topsoil may be due to its poor mobility within the soils because of its high density or ability of the soils to adsorb them. The exception for site 1 may be due to wastes from direct welding and vehicle servicing activities at the site coupled with its downslope location. Like the $\mathrm{Cd}$, the potential source of the $\mathrm{Pb}$ in the soils could be from the anti-knock additives in the waste oils, used lead-acid batteries and waste from weld- 
Impact of waste disposal on groundwater quality in Suame... 28

ing disposed indiscriminately in the area.

The concentrations of $\mathrm{Ni}$ in the top soil and at depth were all within the crustal value except for one sample (i.e. SP6 at $0-30 \mathrm{~cm}$ ), which was slightly above the crustal value. This indicates that the concentration of $\mathrm{Ni}$ in the soils reflect the normal concentration of the parent rock and is in conformity with results obtained by Acheampong et al. (2016). On the contrary, the $\mathrm{Cr}$ concentration of all the samples, except SP2 at $0-30 \mathrm{~cm}$ depth, exceeded the crustal value of $100 \mathrm{ppm}$. Their concentrations were largely higher at depth than at the top and the computed $I_{\text {geo }}$ described them as unpolluted to moderately polluted. Unlike other metals, the $\mathrm{Cr}$ is more naturally occurring and is found in plants and animals aside the geologic media. Thus, its high concentrations above the norm cannot be attributed to only the wastes from metal fabrication and metal plating activities in the area.

\section{Heavy metals in groundwater}

Table 4 shows the concentrations of all the heavy metals analysed in the groundwater samples from the study area. Apart from $\mathrm{Pb}$ and $\mathrm{Ni}$, all the heavy metals analysed had their concentration values within the acceptable WHO drinking water guideline values. The $\mathrm{Pb}$ and $\mathrm{Ni}$ concentrations that were above the WHO guideline values occurred in $84 \%$ and $92 \%$, respectively, of the samples.

Table 4 : Concentrations (in $\mathrm{mg} / \mathrm{l}$ ) of the heavy metal ions in the groundwater

\begin{tabular}{lrrrrrr}
\hline SAMPLE ID & Pb & $\mathbf{C u}$ & $\mathbf{C d}$ & $\mathbf{C r}$ & $\mathbf{N i}$ & $\mathbf{Z n}$ \\
\hline HDW 2 & 0.055 & 0.020 & $<0.002$ & 0.002 & 0.020 & 0.034 \\
HDW 3 & 0.062 & 0.015 & $<0.002$ & 0.026 & 0.026 & 0.066 \\
HDW 5 & 0.018 & 0.016 & $<0.002$ & 0.021 & 0.022 & 0.034 \\
HDW 6 & 0.061 & 0.054 & $<0.002$ & 0.02 & 0.106 & 0.052 \\
HDW 9 & 0.015 & 0.033 & $<0.002$ & 0.022 & 0.115 & 0.022 \\
HDW 13 & 0.013 & 0.032 & $<0.002$ & 0.021 & 0.020 & 0.021 \\
HDW 17 & 0.010 & 0.061 & $<0.002$ & 0.003 & 0.094 & 0.087 \\
HDW 18 & 0.099 & 0.010 & $<0.002$ & 0.006 & 0.088 & 0.064 \\
HDW 20 & 0.087 & 0.081 & $<0.002$ & 0.004 & 0.073 & 0.099 \\
HDW 30 & 0.007 & 0.084 & $<0.002$ & 0.003 & 0.054 & 0.093 \\
HDW 42 & 0.009 & 0.064 & $<0.002$ & 0.002 & 0.092 & 0.028 \\
HDW 46 & 0.010 & 0.027 & $<0.002$ & 0.005 & 0.043 & 0.011 \\
HDW 48 & 0.054 & 0.022 & $<0.002$ & 0.001 & 0.048 & 0.018 \\
HDW 50 & 0.041 & 0.024 & $<0.002$ & 0.001 & 0.091 & 0.067 \\
HDW 55 & 0.077 & 0.034 & $<0.002$ & 0.002 & 0.024 & 0.077 \\
HDW 57 & 0.025 & 0.033 & $<0.002$ & 0.002 & 0.068 & 0.076 \\
HDW 58 & 0.073 & 0.051 & $<0.002$ & 0.007 & 0.066 & 0.099 \\
HDW 59 & 0.021 & 0.027 & $<0.002$ & 0.001 & 0.155 & 0.086 \\
SPG 37 & 0.029 & 0.043 & $<0.002$ & 0.005 & 0.149 & 0.120 \\
HDW 11 & 0.031 & 0.038 & $<0.002$ & 0.008 & 0.155 & 0.113 \\
BH 15 & 0.088 & 0.061 & $<0.002$ & 0.003 & 0.205 & 0.094 \\
BH 19 & 0.075 & 0.055 & $<0.002$ & 0.003 & 0.187 & 0.099 \\
BH 33 & 0.074 & 0.054 & $<0.002$ & 0.004 & 0.135 & 0.095 \\
BH 39 & 0.079 & 0.068 & $<0.002$ & 0.003 & 0.106 & 0.097 \\
Min & 0.007 & 0.010 & & 0.001 & 0.020 & 0.011 \\
Max & 0.099 & 0.084 & $<0.002$ & 0.026 & 0.205 & 0.120 \\
WHO & $\mathbf{0 . 0 1}$ & $\mathbf{1}$ & $\mathbf{0 . 0 0 3}$ & $\mathbf{0 . 0 5}$ & $\mathbf{0 . 0 2}$ & $\mathbf{3}$ \\
\hline
\end{tabular}




\section{9}

Appiah-Adjei et al.

Although Cd was very significant in the soil at both the $0-30 \mathrm{~cm}$ and $30-60 \mathrm{~cm}$ depths to levels of heavily polluting them, its levels in the groundwater were all below $0.002 \mathrm{mg} / \mathrm{l}$. This, possibly, is an indication that the soil had been adsorbing the $\mathrm{Cd}$ (Ramachandran and D'Souza, 1999; Meng et al., 2008) from the recharge waters and protecting the groundwater from $\mathrm{Cd}$ pollution. The situation may persist as long as the adsorptive capacity of the soil is not exceeded and $\mathrm{Cd}$ transport through the soils has not reached it breakthrough point. On the other hand, continuous discharge of $\mathrm{Cd}$ waste into the environment with time would overcome the situation and pollute the groundwater.

Fig. 4 shows the distribution of $\mathrm{Ni}$ and $\mathrm{Pb}$ concentrations in the groundwater of the Suame area. Generally, the concentration of $\mathrm{Ni}$ in groundwater for almost the whole study area is above the WHO acceptable limit (Fig. 4a), except in some isolated locations (i.e. south of Magazine, north of Old Suame and west of New Suame) where they are within the acceptable limits. There is no regular pattern in its distribution in the area, but it tends to decrease away from Magazine, Bohyen Kropo and Krofrom areas towards the area between New Suame and Old Suame. The observed higher concentrations of $\mathrm{Ni}$ in the groundwater is quite surprising since it was not observed in the soils at both the $0-30 \mathrm{~cm}$ and $30-60 \mathrm{~cm}$ depths. Potentially, its source may be from interaction of the groundwater with surface water in the area since the groundwater levels are very shallow and up to almost the ground surface in some locations.

Similarly, the $\mathrm{Pb}$ concentrations in the groundwater for most of the study area (Fig. 4b) were above the WHO guideline value, except in isolated locations south of Bohyen Kropo, Magazine and New Suame. Like the $\mathrm{Ni}$, the $\mathrm{Pb}$ distribution in the groundwater of the area does not show any distinct pattern, but tends to have higher concentrations within the Magazine area and, then, east of Krofrom towards Bohyen Kropo. Traces of $\mathrm{Pb}$ above the crustal values were also observed in soils with depth and may be an indication of its transport from the ground surface through the soil to the groundwater. Prolonged usage of the groundwater without

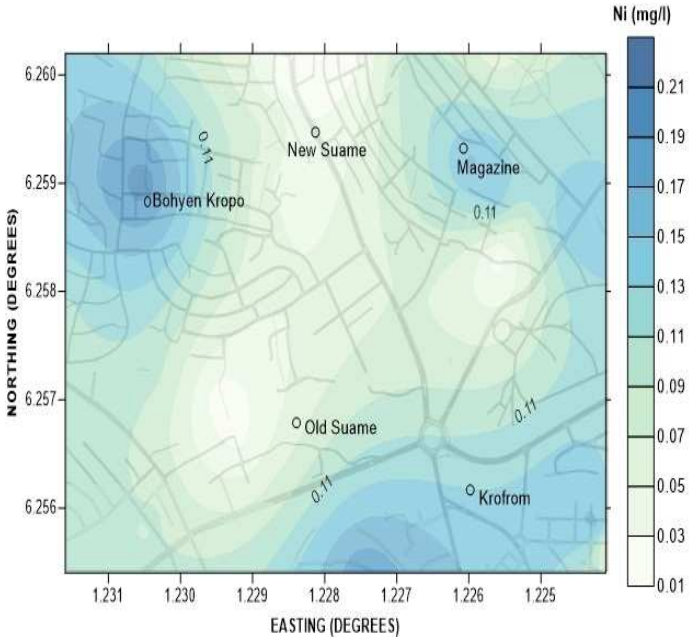

(a)

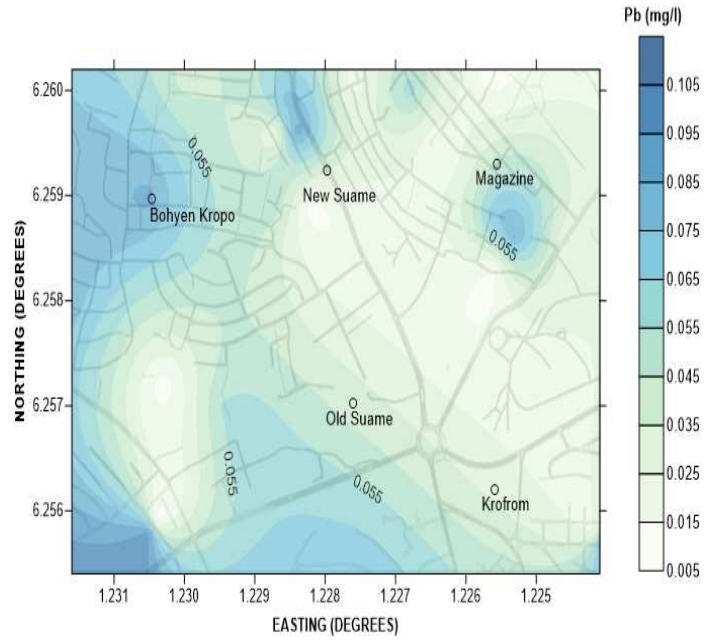

(b)

Fig. 4: Distribution of (a) nickel and (b) lead concentrations in groundwater of the study area 
Impact of waste disposal on groundwater quality in Suame... 30

reducing $\mathrm{Ni}$ and $\mathrm{Pb}$ to acceptable levels may have long term health effects on the consumers. Excessive $\mathrm{Pb}$ and $\mathrm{Ni}$ in water could be removed by filtration using activated carbon (Aziz et al., 2005; Onundi et al., 2010; Karnib et al., 2014) and thin film composite membranes (Barakat, 2011; Le and Nunes, 2016) among others.

\section{CONCLUSIONS}

The study has investigated the potential impact of waste oil and metal disposal on groundwater quality in Suame, Ghana, through mapping of the potential sources and quantities of waste oil spilled and their effects on both soil and groundwater through heavy metal presence. The study results indicate that a total of sixtythree groundwater supply points (comprising 46 hand-dug wells, 9 boreholes and 8 springs) are located in the study area; out of which 27 are within the Magazine area. Also, 72 potential oil waste pollution sites (comprising 62 garages and 10 filling stations), spilling an estimated 60,295 litres of waste oil annually with about $96 \%$ from the garages, were mapped.

The evaluation of heavy metal presence in the soils indicates that $\mathrm{Ni}$ concentrations in the soils, generally, reflect the parent rock lithology and has not polluted the soil. However, the soils were observed to be unpolluted to moderately polluted with $\mathrm{Cu}, \mathrm{Cr}$ and $\mathrm{Zn}$, and moderately to heavily polluted with $\mathrm{Pb}$ and $\mathrm{Cd}$. Unlike the soils, the heavy metals presence in the groundwater of the area were mostly within acceptable limits except for $\mathrm{Pb}$ and $\mathrm{Ni}$. $84 \%$ and $92 \%$ of the groundwater supply points had their levels of $\mathrm{Pb}$ and $\mathrm{Ni}$, respectively, above the $\mathrm{WHO}$ guideline values for drinking water. The $\mathrm{Pb}$ levels in the groundwater was not surprising since traces of it were observed in the soils (i.e. at depths of $0-30 \mathrm{~cm}$ and $30-60 \mathrm{~cm}$ ) indicating its transport from the oil waste spills or activities on the ground surface through the soil. The high Ni levels, on the other hand, could not be traced directly to activities on the ground surface since they were not observed in the soils. Thus, it makes attributing groundwater pollution in the area, entirely, to the waste oil spillages and activities in the area inconclusive. This notwithstanding, the study has showed that the groundwater in the area is unsuitable for drinking because it is polluted with high levels of $\mathrm{Pb}$ and $\mathrm{Ni}$. The groundwater, therefore, requires some prior treatment for the $\mathrm{Pb}$ and $\mathrm{Ni}$ contents to be reduced to acceptable limits before being used as drinking water.

\section{ACKNOWLEDGEMENTS}

The authors are very grateful to the Provost, College of Engineering, KNUST, Ghana who initiated the "Suame Collaborative Research Project" under which this study was carried and the Department of Geological Engineering, KNUST, Ghana for funding the laboratory tests.

\section{REFERENCES}

Abdul-Razak, A., Asiedu, A. B., EntsuaMensah, R. E. M. and deGraft-Johnson, K. A. A. (2009). "Assessment of the water quality of the Oti River in Ghana". West African Journal of Applied Ecology, 15: 45-60.

Acheampong, F., Akenten, J. W., Imoro, R., Agbesie, H. R. and Abeyie, D. (2016). "Evaluation of heavy metal pollution in Suame industrial area, Kumasi, Ghana". Journal of Health and Pollution, 6(10): 56 63.

Adepelumi, A. A., Ako, B. D. and Ajayi, T. R. (2001). "Groundwater contamination in the basement-complex area of Ile-Ife, southwestern Nigeria: A case study using the electricalresistivity geophysical method". Hydrogeology Journal, 9(6): $611-622$.

Adeya, C. N. (2008). The Suame manufacturing cluster in Ghana. In: Zeng, D. Z. (Editor) Knowledge, Technology, and Cluster-Based Growth in Africa. The World Bank, Washington.

Ahmadipour, F. Bahramifar, N. and Ghasempouri, S. M. (2014). "Fractionation and mobility of cadmium and lead in soils of Amol 


\section{Appiah-Adjei et al.}

area in Iran, using the modified BCR sequential extraction method". Chemical Speciation and Bioavailability, 26(1): $31-36$.

Annapoorna, H. and Janardhana, M. R. (2015). "Assessment of groundwater quality for drinking purpose in rural areas surrounding a defunct copper mine". Aquatic Procedia, 4: $685-692$.

Ansa-Asare, O. D., Darko, H. F. and Asante, K. A. (2009). "Groundwater quality assessment of Akatsi, Adidome and Ho Districts in the Volta Region of Ghana". Desalination, 248(1 $-3): 446-452$.

Apambire, W. B., Boyle, D. R. and Michel, F. A. (1997). "Geochemistry, genesis, and health implications of fluoriferous groundwaters in the upper regions of Ghana". Environmental Geology, 33(1): $13-24$.

Aziz, H. A., Adlan, M. N., Hui, C. S., Zahari, M. S. M. and Hameed, B. H. (2005). "Removal of $\mathrm{Ni}, \mathrm{Cd}, \mathrm{Pb}, \mathrm{Zn}$ and colour from aqueous solution using potential low cost absorbent." Indian Journal of Engineering and Material Sciences, 12: 248 - 258.

Azongo, N. A (2007). SMIDO industrial development policy blueprint. Suame Magazine Industrial Development Organization, $\mathrm{Ku}-$ masi.

Barakat, M. A. (2011). "New trends in removing heavy metals from industrial wastewater". Arabian Journal of Chemistry, 4(4): 361 $-377$.

Chen, J., Taniguchi, M., Liu, G. Miyaoka, K., Onodera, S., Tokunaga, T. and Fukushima, Y. (2007). "Nitrate pollution of groundwater in the Yellow River delta, China". Hydrogeology Journal, 15(8): 1605-1614.

Chettri, M. and Smith, G. D. (1995). "Nitrate pollution in groundwater in selected districts of Nepal". Hydrogeology Journal, 3(1):.7176.
Chibuike, G. U. and Obiora, S. C. (2014). "Heavy metal polluted soils: effect on plants and Bioremediation Methods," Applied and Environmental Soil Science, Doi:10.1155/2014/752708

Duffus, J. H. (2002). "Heavy metals - a meaningless term". Pure and Applied Chemistry, 74: 793-807.

Ettler, V. (2016). "Soil contamination near nonferrous metal smelters: a review". Applied Geochemistry, 64: 56-74.

Fawell, J. and Nieuwenhuijsen, M. J. (2003). "Contaminants in drinking water". British Medical Bulletin, 68: 199-208.

Friberg, L., Kjellstroem, T. and Nordberg, G. F. (1986). "A handbook on the toxicology of metals". Elsevier, Amsterdam, 11: 130-184.

Garg, V. K. and Totawat, K. L. (2004). "Ground water contamination in the area adjoining zinc smelter effluent stream". Journal of Environmental Science and Engineering, 46(1): $61-64$.

Haest, P. J., Lookman, R., Van Keer, I., Patyn, J., Bronders, J., Joris, M., Bellon, J. and De Smedt, F. (2010). "Containment of groundwater pollution (methyl tertiary butyl ether and benzene) to protect a drinking-water production site in Belgium". Hydrogeology Journal, 18(8): 1917-1925.

Hu, H., Jin, Q. and Kavan, P. (2014). “A study of heavy metal pollution in China: current status, pollution control policies and counter measures". Sustainability, 6: 5820-5838.

Japan International Development Cooperation (JICA). (2013). The study on the comprehensive urban development plan for Greater $\mathrm{Ku}$ masi in the Republic of Ghana final report: supporting documents. Japan International Cooperation Agency; Oriental Consultants Co., Ltd.; CTI Engineering International Co., 
Impact of waste disposal on groundwater quality in Suame... 32

Ltd. and ALMEC Corporation, Tokyo.

Kacaroglu, F. and Gunay, G. (1997). "Impacts of human activities on groundwater quality of an alluvial aquifer: A case study of the Eskisehir Plain, Turkey". Hydrogeology Journal, 5(3): 60-70.

Karnib, M., Kabbani, A., Holail, H. and Olama, Z. (2014). "Heavy Metals Removal Using Activated Carbon, Silica and Silica Activated Carbon Composite". Energy Procedia, 50: $113-120$.

Kesse, G. O. (1985). The mineral and rock resources in Ghana. A. A. Balkema, Rotterdam.

Krishna kumar, S., Logeshkumaran, A., Magesh, N.S., Godson, P. S. and Chandraseker, N. (2015). "Hydrogeochemistry and application of water quality index (WQI) for groundwater quality assessment, Anna Nagar, part of Chennai City, Tamil Nadu, India". Applied Water Science, 5(4): $335-343$.

Le, N. L. and Nune, S. P. (2016). "Materials and membrane technologies for water and energy sustainability". Sustainable Materials and Technologies, 7: $1-28$.

Lewis, W. J., Foster, S. S. D. and Drasar, B. S. (1982). The risk of groundwater pollution by on-site sanitation in developing countries. IRCWD Report 01/82, IRCWD, Duebendorf.

Lusilao-Makiese, J. G., Cukrowska, E. M., Tessier, E., Amouroux, D. and Weiersbye, I. (2013). "The impact of post gold mining on mercury pollution in the West Rand region, Gauteng, South Africa". Journal of Geochemical Exploration, 134: 111-119.

Meng, Z. F, Zhang, Y. P., and Zhang, Z. Q. (2008). "Simultaneous adsorption of phenol and cadmium on atmospheric soil". Journal of Hazardous Materials, 159: 492-498.
Muller, G. (1969). "Index of geoaccumulation in sediments of the Rhine River". Geological Journal, 2: 108-118.

Newbury, T. K. (1997). "Possible accumulation of heavy metals around offshore oil production facilities in Beaufort Sea". Arctic, 32(1): 42-45.

Nkansah, M. A., Boadi, N. O. and Badu, M. (2010). "Assessment of the quality of water from hand-dug wells in Ghana". Environmental Health Insights, 4: 7 - 12.

Obeng, G. (2002). Kumasi Suame Magazine A Background Paper. Technology Consultancy Centre, KNUST, Kumasi.

Ojiegbe, R. U. (2006). "Assessment of the effects of oil spillage on groundwater in an inland basin of south eastern Nigeria". International Journal of Natural and Applied Sciences, 2(1): 19-23.

Onundi, Y. B., Mamun, A. A, Al Khatib, M. F. and Ahmed, Y. M (2010). "Adsorption of copper, nickel and lead ions from synthetic semiconductor industrial wastewater by palm shell activated carbon". International Journal of Science and Technology, 7 (4): 751-758.

Parris, K. (2011). "Impact of agriculture on water pollution in OECD countries: recent trends and future prospects". International Journal of Water Resources Development, 27 (1): 33-52.

Ramachandran, V. and D'Souza, T. J. (1999). "Adsorption of Cadmium by Indian Soils". Water, Air, and Soil Pollution. 111(1): 225 -234 .

Richard, A. G. and Richard, A. M. (1977). "Trace metals in sediments of Ravitan Bay". Marine Pollution Bulletin, 8: 188-192.

Shen, Y. Lei, H., Yang, D. and Kanae, S. (2011). "Effects of agricultural activities on 


\section{Appiah-Adjei et al.}

nitrate contamination of groundwater in a Yellow River irrigated region". IAHS Publications, 348: 73-80.

Suame Magazine Industrial Development Organization (SMIDO). (2012). Towards a new industrial village. Suame Magazine Industrial Development Organization, Kumasi.

Taylor, S. R. (1964). "Abundance of chemical elements in the continental crust: a new table". Geochimica Cosmochimica Acta, 28:
1273-1285.

Todd, D. K. and Mays, L. W. (2005). Groundwater Hydrology, $3^{\text {rd }}$ edition. John Wiley and Sons Inc., New York.

WHO (2011). Guidelines for Drinking Water Quality. $4^{\text {th }}$ Edition, WHO, Geneva.

Xu, Y. and Usher, B. (2006). Groundwater pollution in Africa. Taylor and Francis/Balkema, The Netherlands. 